\title{
Analyzing the retail investor's expectation from their fiduciary with respect to Mutual Fund Investors
}

\author{
Meghana Patil ${ }^{1}$, Shilpa Parkhi ${ }^{2}$ \\ \{meghana166@gmail.com ${ }^{1}$,deputy.director@siom.in $\left.{ }^{2}\right\}$ \\ Symbiosis International (Deemed University), India ${ }^{1,2}$
}

\begin{abstract}
Over the past decades there are few changes in the law of fiduciary but the economic and market environment in which the fiduciary law applies has changed drastically. Various factors such as globalization, population growth and natural resource scarcity, internet, social media, changing community and stakeholder's norm impacted significantly to the evolution of the fiduciary duty. There is need to study the fiduciary duty as the duties have not changed much but has gained more importance in the volatile world and secondly The Indian Mutual fund industry is fast growing industry since last few years. The younger generation is more attracted towards mutual fund as an investment avenue. To penetrate this segment of investors the fund managers should know what are their expectation from the fiduciaries. The findings of the research are that the investors expect that their fiduciary should give the highest priority to the client's interest. The research result basically helpful for the Fund managers and the policy makers and regulators to consider the investor's expectation from their fiduciary in their strategy formulation and policy design.
\end{abstract}

Keywords: Fiduciary duty, mutual fund, Environmental, social and Governance factors (ESG)

\section{Introduction}

"The concept of fiduciary duty is organic, not static. It will continue to evolve as society changes, not least in response to the urgent need for us to move towards an environmentally, economically and socially sustainable financial system."

\section{Paul Watchman (Honorary Professor, School of Law, University of Glasgow}

Over the past decades there are little changes in the law of fiduciary but the economic and market environment in which the fiduciary law applies has changed drastically. Various factors such as globalization, population growth and natural resource scarcity, internet, social media, changing community and stakeholder's norm impacted significantly to the evolution of the fiduciary duty. Also the relevance of ESG factors has found to be prominent in investment risk and return and hence should be included in the fiduciary duties. Today's financial crises has many reasons but one of the reason among them is the institutional investors who are the major contributors of the financial market who failed to exercise their power and responsibility. Here the Power is of playing active role in board structure and governance, director elections, executive compensation ,stock options, proxy proposals, dividend policy and so on. Responsibility means to act in the best interest of their beneficiaries or principals. 


\section{Need for the study}

While the fiduciary duty concept is still very much relevant today the institutional investors with fiduciary duty need to address some fundamental questions like,

1. Whether the investors are considering ESG (Environmental, social and Governance factors) issues in their investment decision making?

2. Whether they should demand higher standard of ESG performance form the companies in which they are investing

3. Whether the investors consider their responsibility to support the integrity and stability of the financial system

The project report "Fiduciary Duty in 21 st Century "published by the joint efforts of United Nation's Principles Of Responsible Investment, UNEP FI, UNEP Inquiry and UN Global Compact concluded that "Failing to consider ESG issues in investment practices which is one of the long term investment value drivers is a failure of fiduciary duty.

Over the period of time the law relating to fiduciary duty has not changed drastically however there is significant increase in a requirement of disclosure of ESG issues by asset owner and investment managers in the context of stewardship codes. The disclosure will help the investors to get engaged with the companies in which they have invested. The soft law measures has encourages the investors to pay greater attention to ESG issues.

There are many countries that have shown their concern about the ESG issues and want the institutional investors to adopt, publish policies on ESG issues and also should report on the implementation of the policies. Mandatory reporting are improving quality and quantity of the information but still there a need to take an action in this area. There are many challenges to implementation process as the domestic companies can take it as an additional regulatory requirement.The reluctance is due to the national policy may not align with the international practice. There is misconception that ESG issues are not important to investment practice and performance. Some may also think that ESG issues are not important to short term but it is for long term purpose. Considering all the factors there is a need to study fiduciary duty in the reformed way.

\section{Objectives of the study}

- To understand the concept of fiduciary duty.

- To know the scenario of fiduciary duty at global and domestic level.

- To understand whether the investors are with the prime objective of the investment.

- To find out the expectation of fiduciary duty of the fund owner from fund manager of mutual fund.

- To assist the fund manager to prioritizing the expectations of the fund owners for making further investment decisions. 
Scope of the research: In the financial industry the fiduciary relationship is in existence in every investment criteria but in the mutual fund industry it is prominent so the study will concentrate on the mutual fund investors only

\section{Limitation}

Private pension plan face conflict of minimizing the plan contribution to maximizing the company's earning whereas the public pension plan faces another conflict like political pressure to invest in pet projects. In Insurance sector, the investment is for life cover and not for investment .Between Insurance and investment there are some superficial similarities and that causes the confusion. Both involve giving money to financial services in exchange of future benefit .In case of insurance the purpose is to cover the financial aspect of risk in case of property life health legal liability and many other kinds.

\section{Theoretical construct}

\section{Fiduciary:}

A fiduciary is a person who acts, manage assets on behalf of another person. A fiduciary is a person or organization that owes to another the duties of good faith and trust.

\section{Fiduciary duty:}

Fiduciary duty exists when one person agrees to act on behalf of another. Generally, investment manager, fund managers owe a fiduciary duty to their clients. It is a legal relationship of confidence between two or more parties. The fiduciary act in the interest of its beneficiary all the time and he must not put his personal interest before the interest of its beneficiary. He also should not put the place where his fiduciary duty towards client contradicts with a fiduciary duty to any other entity.

In every jurisdiction the different standard of fiduciary are prevailing but still there are some common themes like

- Loyalty: it says faithfulness while taking the decision to the interest of the beneficiaries

- The control of cost and managing the conflicts of interest

- Transparency and accountability

- Prudence and care taking the utmost care in managing the investment of the beneficiaries

- Compliance with terms of the operative documents and applicable laws.

But mainly fiduciary duty is divided into duty of loyalty and care. Both are addressing the risk. But duty of loyalty addresses the risk of misappropriation and duty of care addresses the risk of negligence. 


\section{Duty of loyalty}

Duty of loyalty mainly negative. It is duty to prevent you from doing misconduct and refrain from self-interested behavior and avoid conflict of interest

\section{Duty of care}

The duty of care in the contrast of loyalty is positive and elaborates what is should be done by the fiduciary. It focuses on process and the diligence. The duty of care focuses on the process and the diligence the fiduciary must undertake. Further the duty of diligence is to make a reasonable efforts $t$ achieve the beneficiary's objective.

\section{Changing the landscape of fiduciary duty}

\section{Global context:}

In January 2016, The United Nations Principle of Responsible Investment ( UNPRI ), United Nations Environment Programme Finance Initiatives (UNEP FI) and the Generation Foundation has published the report "Fiduciary Duty in 21st Century ".After doing in depth assessment in 8 countries (US, Canada, Germany, Australia, South Africa ,Brazil, Japan And UK) concludes that "fiduciary duties have played and continued to play , a critical role in ensuring that fiduciaries are loyal to their beneficiaries and carry out their duties in prudent manner further in the 21 st century era fiduciary duty has to alter according to the global challenges like climate change, financial crises and social issues i.e Environment. Social and Governance factors. Failing to consider these long term investment value drivers in investment practices is failure of fiduciary duty.

\section{Indian context:}

The financial stability and development council has proposed a committee for setting up a stewardship code for institutional investors to discharge their fiduciary duty. The committee is comprised of officials of the Securities and Exchange Board of India (SEBI) . The Insurance Regulatory Development Authority of INDIA (IRDA) and The Pension Fund Regulatory Authority Of India. The committee formulated the set of guidelines which is based on the guidelines adopted by the UK's Financial Reporting Council 2010.

Mr. Amit Tondon who is managing director of institutional investor's advisory firm said that there is an urgent need of such codes. The regulation for the companies are already there to adopt the best practices but there is a need to have such kind of rules and regulation in case of money managers who manage the money of other people .They have a fiduciary duty towards those whose money they manage.

SEBI has already set some rules for asset management firms but SEBI's nudging to mutual fund fall short of a full set of principles.

Pension fund regulatory authority and The Insurance Regulatory Development Authority of INDIA has already come up with stewardship code for pension fund and insurance fund. 


\section{Literature Review}

\section{Institutional investor}

Institutional investors are the major players (upto35\%) in global investment [18]. In many countries the institutional investors are equity owners in publicly listed companies and their size and influence is continuously growing. [6] Today institutional investors hold large stock in the company, and they are able to bear the cost of corporate engagement alone. [1] In the investment fiduciary relationship, beneficiaries and society are vulnerable to abuse at the hands of fiduciary. [16]

This can be explained with the following reasons:

1. The control over the management of assets is given to the fiduciary that may create a conflict of interest.

2. Fiduciary are more expertise than the beneficiary.

3. The investment prudence or breach of trust may not evident immediately.

4. Like a direct investment in shares, the beneficiary do not have ability to avoid a risk by timely withdrawing the assets from the hands of fiduciary.

5. The heavy reliance of beneficiary on fiduciary create both personal and economic risk.

From the above points it is evident that the fiduciary relationship is based on trust and confidence .They are the protectors the beneficiary's fund and should strive to maintain the standard demanded by the beneficiaries and society.

Even though the conflict of the interest is in the existence across all over the money management business, but it is present in different forms in each sector.

The mutual fund Industry and fiduciary duty has close relation due to the following reason

1. The mutual fund has the unique structure - As the sponsor establishes the AMC, and board both, there is the domination of fund boards by the chairmen and chief executives. The same people also control the AMC. So indirectly advisor dominates board.[5],[7] As the advisors dominates the board the fee negotiation cannot be truly arm's length it means fees charged by mutual fund are excessive as compared to other invest management charged their fees. As the fees charged is excessive their fiduciary responsibility increases in terms of due diligence, proxy voting and compilation programme. [8] In mutual fund industry there is a direct conflict between the fiduciary duty to share owners and the business interest of the fund managers. Apart from this relationship various research papers were reviewed

2. On the financial literacy, The independent financial advisors (IFA) play very important role in the distribution of mutual fund products. They interact with the investors regularity and advise them on the assets allocation and diversification .But here the biggest risk of financial literacy of IFA .It can be result into mis-selling. So regulators are supposed to arrange the financial literacy program to tier 2 cities and rural areas.[24] 
3. Laws related to investors protection, transparency in reporting ,taxation, insider trading play important role in managing the conflict of interest between the fund and fund investors.[11] The supply side issues like bank concentration [13],breadth of distribution channel restriction from entering the securities business [4] ease of entry into fund industry like cost of setting up new fund are the contributors of growth of the fund industry.

4. The demand side factors like education, financial literacy, presence of information sources ,transparency and transaction cost also can be used to determine the characteristics of mutual fund industry [5]

5. The purchase decision of the mutual fund investors are influenced by salient features like face fees, front end loads and commissions and attention seeker information.[3] Some of the findings also say that there is negative correlation between fund flow and the commission charged by the brokerage firms. Surprisingly there is no relation found between operating expenses and fund flow.

6. In case of financial literacy, the financial literacy is not related to the performance of actively managed funds but the overconfidence might prevent investing passively.

7. While examining the economic substitute asset class for mutual fund, the equity flow is negatively correlated to the flow of money market and precious metal fund [14]

8. The rule of restriction on entry load of mutual fund in 2009 has affected the functioning of mutual fund industry. Due to this the mutual fund houses and distributors had to restructure their business. But there is no supportive evidence for the claim that the abolition of entry loads had hampered the penetration of mutual fund [2] The Indian mutual fund industry is characterized by the lack of proper distribution channels, entry loads, governance and risk management, technology and low retail participants [18]

9. The study focuses on financial intermediaries and their economic role has provided six major findings, financial managers facilitates small investors to use actively managed fund .secondly, .Kickback payments are used to compensate advisors for price discrimination portfolio managers competition reduces kickbacks but increases independent advisory services . third Mutual fund payment of kickbacks are associated with high management fees and low fund performance. Fourthly, mutual fund distribution channels impact fund performance. Fifth, the kickbacks can be reduced by competition among the actively managed fund. And lastly fund investors would benefit with the better disclosure of kickbacks[12]

10. Mutual fund kickbacks are associated with higher management fees and lower fund performance. when the investors are sophisticated kickbacks affects only high net worth investors. If the investors are unsophisticated all the investors get negatively impacted with kickbacks

11. When the fund performance is poor then the fund outflow increases and vice a versa . Both the retail and institutional investors behave in the same manner on the performance attributes of the firm.[11] Investors consider the fund performance in buying decision but they don't consider it while making selling decision. 


\section{The Indian Mutual Fund Industry :}

From past few years the Indian Mutual Fund industry is growing at a fast pace. The number of mutual portfolios has increased to 74.6 million as of June 18. Assets under management of mutual fund industry stood at 23.06 lakhs crores (US\$343.90 millions).

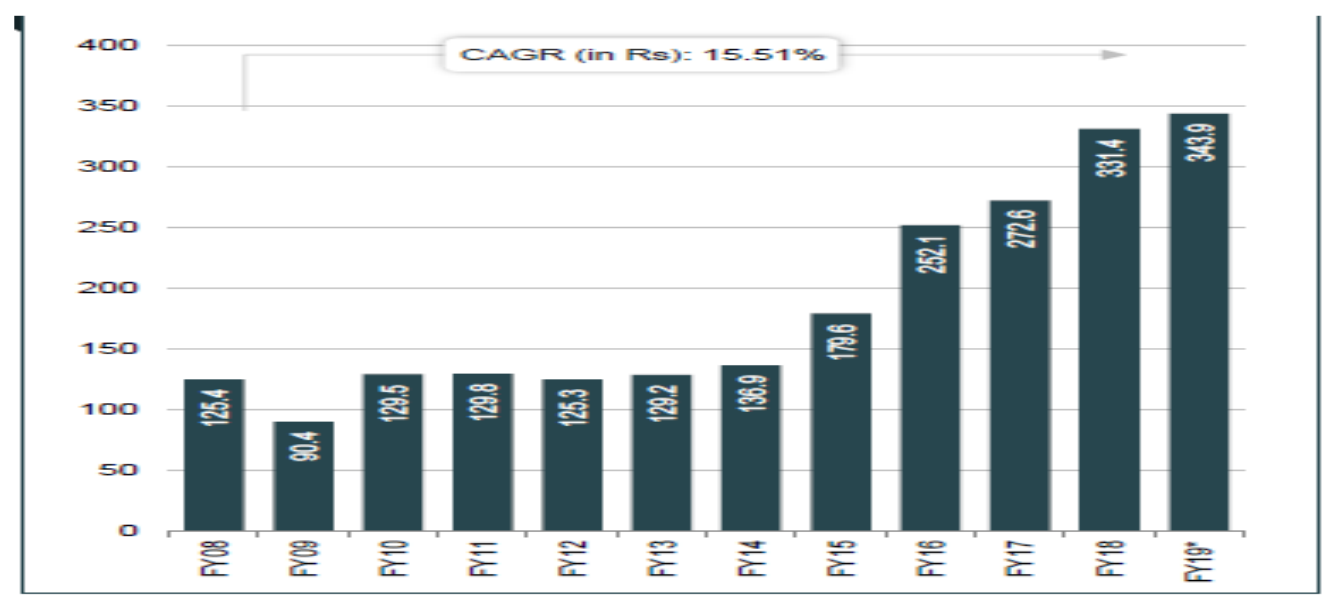

Figure:1 Growth of Mutual fund Industry in India. Source: Association of Mutual Funds AMFI, Aranca Research

Inflows in Indian Mutual fund schemes via SIP (systematic Investment Plan) route reached Rs. 67,190 crores (US $\$ 10.43$ billion) . Equity Mutual fund have registered a net inflow of Rs. 38,474 crores (US $\$ 5.74$ billion).

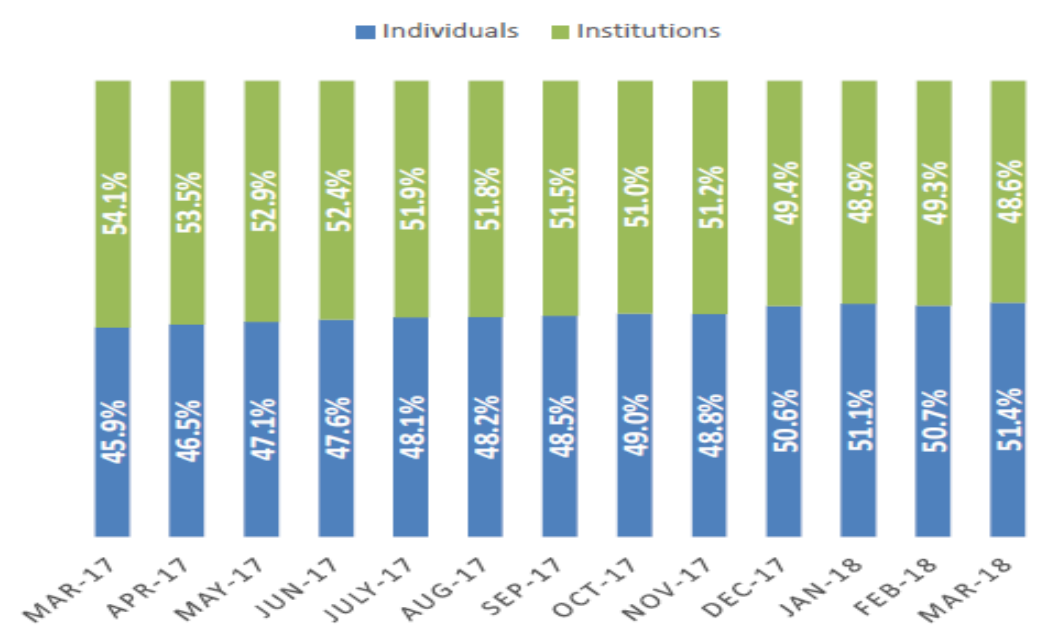

Figure 2: Investor's breakup. Source: Association of Mutual Funds - AMFI 
Individual investors retail plus HNWI hold now higher share of industry's assets i.e. 51.4\% in March 2018 as compared to $45.9 \%$ in 2017.Institutional investors account for $48.6 \%$.Overall individual contribution has increased in Mutual fund industry.

There is need to study the expectation of fund owner from fund managers.

\section{Research methodology}

Sample size: Judgmental sampling technique applied to decide the sample size .The sample will include the investors who invest in mutual fund.

The data collection method is used through primary and secondary source. A structured questionnaire is prepared including demographic factors along with expectation of the fund owners on the following points.

Loyalty, prudence, cost control, management of conflict of interest, transparency and accountability and compliance with legal formalities.

Further we have also found out whether there is any association between the age of the investors and the investment avenue they select. For this purpose the hypothesis has formulated

Ho: There is an association no between the age and the selection of investment avenues.

H1: There is an association between the age and the selection of investment avenues.

\section{DATA ANALYSIS}

\section{Demographic analysis}

The data collection method is structured questionnaire emailed to around 70 people in the Mumbai area out of which we received 51 responses. Most of the respondents 41(82\%) are of 21-40 age and $14 \%$ are $40-60$ age and $4 \%$ are 60 and above age. The average income of the majority of respondents is 5, 00,000-10,00,000 annually. 


\section{Analysis of different investment avenues}

In which of the following investment avenues you have nvested ? select which is applicable to you.

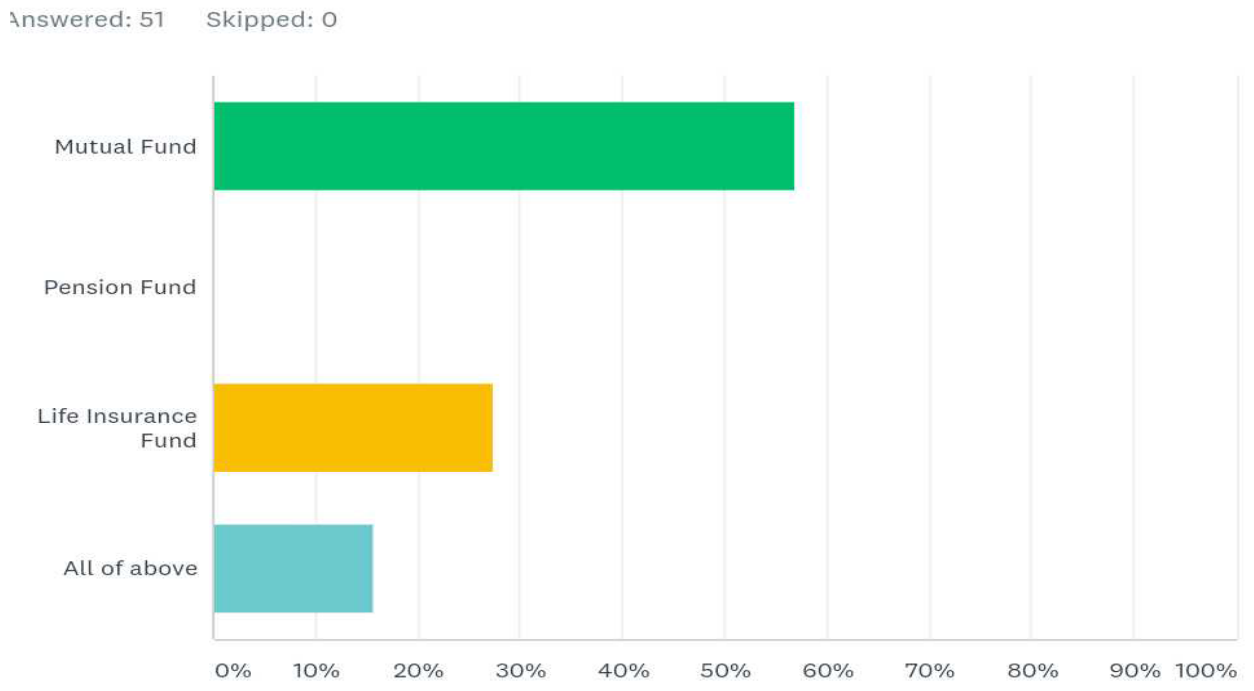

Figure: 1 different investment option

TOTAL 51 respondents answered this question and out of which 29 respondents opted for mutual fund which is $56.86 \% .14$ respondent opted For life insurance fund $(27.45 \%)$ and 8 have opted for all of above.

\section{Analysis of charging investment fees to mutual fund:}

Do you think the fees you paid for investment in mutual fund is more than any other investment fee?

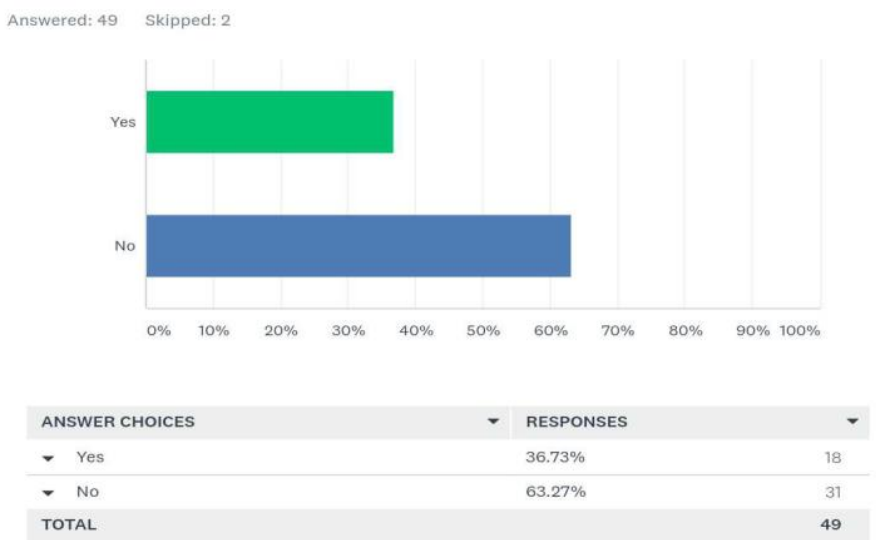

Figure 2: Fees charged for mutual fund 
Out of 49 respondents who answered this question 31(63.27\%) said "no" and 18 respondents said "yes".

Analysis of investment objective of different types of investment such as pension fund, Insurance fund and Mutual fund.

\section{I have opted the pension fund to get my specified retirement benefit.}

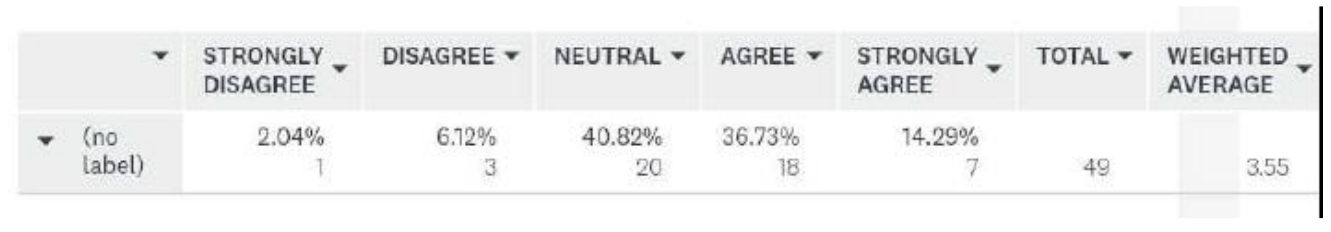

Figure 3: investment objective of pension fund

Out of 49 people responded to this question 25 people were agreed that they are investing in the pension fund to get their retirement benefit and 20 people were neutral about the statement rest 4 people were disagreeing with this motive of investment.

\section{I have opted Life Insurance policy with a main motive to cover my life.}

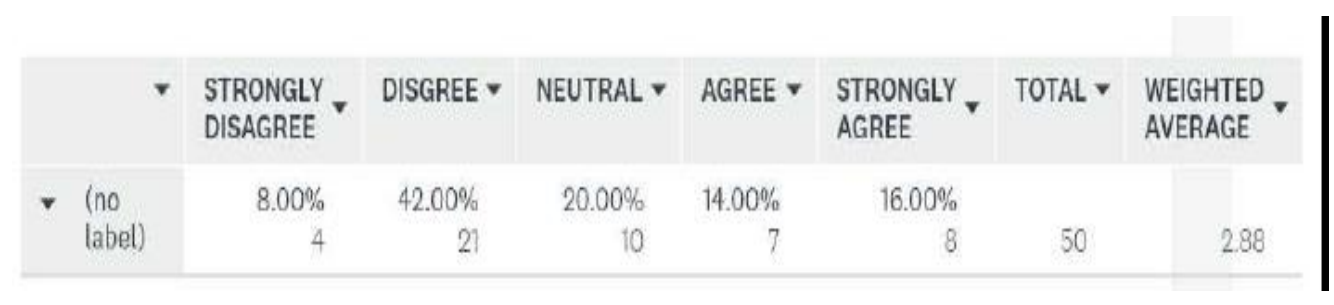

Figure 4: investment objective of Life Insurance fund

Out of 50 respondents to this question, 25 (50\%)are disagreeing with the motive of "Life cover "of insurance fund. Only $35 \%$ of respondents are agreeing with the life cover motive. 


\section{I have invested in mutual fund with a objective to earn risk adjusted return.}

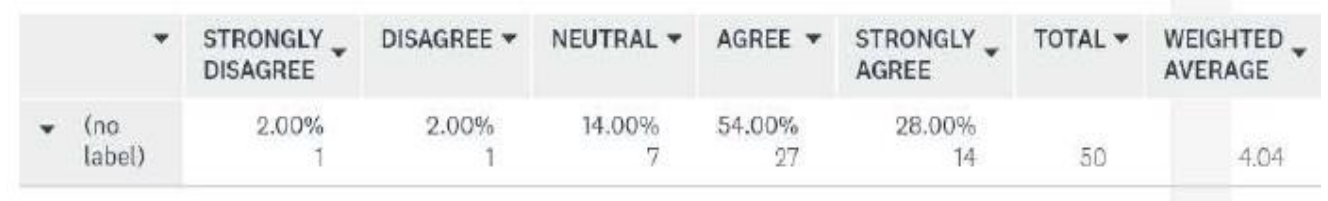

Figure 5: Investment objective of mutual fund

Out of 50 respondents, $41(82 \%)$ respondents are agreeing with the motive of "Risk adjusted return" of mutual fund investment. This may be because most of our respondents are the investors of mutual fund.

\section{Analysis of expectation of fiduciary responsibility:}

\section{Mutual fund manager has a more fiduciary responsibility than life Insurance and Pension Fund as there is excessive fees charged.}

\begin{tabular}{|c|c|c|c|c|c|c|c|}
\hline$\checkmark$ & $\begin{array}{l}\text { STRONGLY } \\
\text { DISAGREE }\end{array}$ & DISAGREE * & NEUTRAL $\mathbf{v}$ & AGREE - & $\begin{array}{l}\text { STRONGLY } \\
\text { AGREE }\end{array}$ & TOTAL * & $\begin{array}{l}\text { WEIGHTED } \\
\text { AVERAGE }\end{array}$ \\
\hline $\begin{array}{ll}\text { - } & \text { (no } \\
& \text { label) }\end{array}$ & $2.00 \%$ & $\begin{array}{r}6.00 \% \\
3\end{array}$ & $\begin{array}{r}42.00 \% \\
21\end{array}$ & $\begin{array}{r}34.00 \% \\
17\end{array}$ & $\begin{array}{r}16.00 \% \\
8\end{array}$ & 50 & 356 \\
\hline
\end{tabular}

Figure 6: Linkage of excessive fees charged with fiduciary responsibility

Out of 50 respondents, $25(50 \%)$ are agreeing that fees charged by mutual fund are excessive than pension fund and insurance fund. Round 21 respondents $(42 \%)$ are neutral about the statement. and 4 respondents $(8 \%)$ are disagreeing with the statement. It means fees charged by the fiduciaries is nothing to do with responsibilities they have to discharged.

In the question no. 7 we asked the respondents to rate their expectations of the Likert 7 point scale as 7 being extremely important and 1 being not at all important.

As per the weighted average analysis, the expectation of to managing assets in a such a way that leads to client's interest in the highest priority has gained a maximum weightage (5.79) followed by To give a proper disclosure of financial risk and return whereas Disclosing the amount of compensation that the fiduciary would get due to client's investment has a last priority (3.148). 


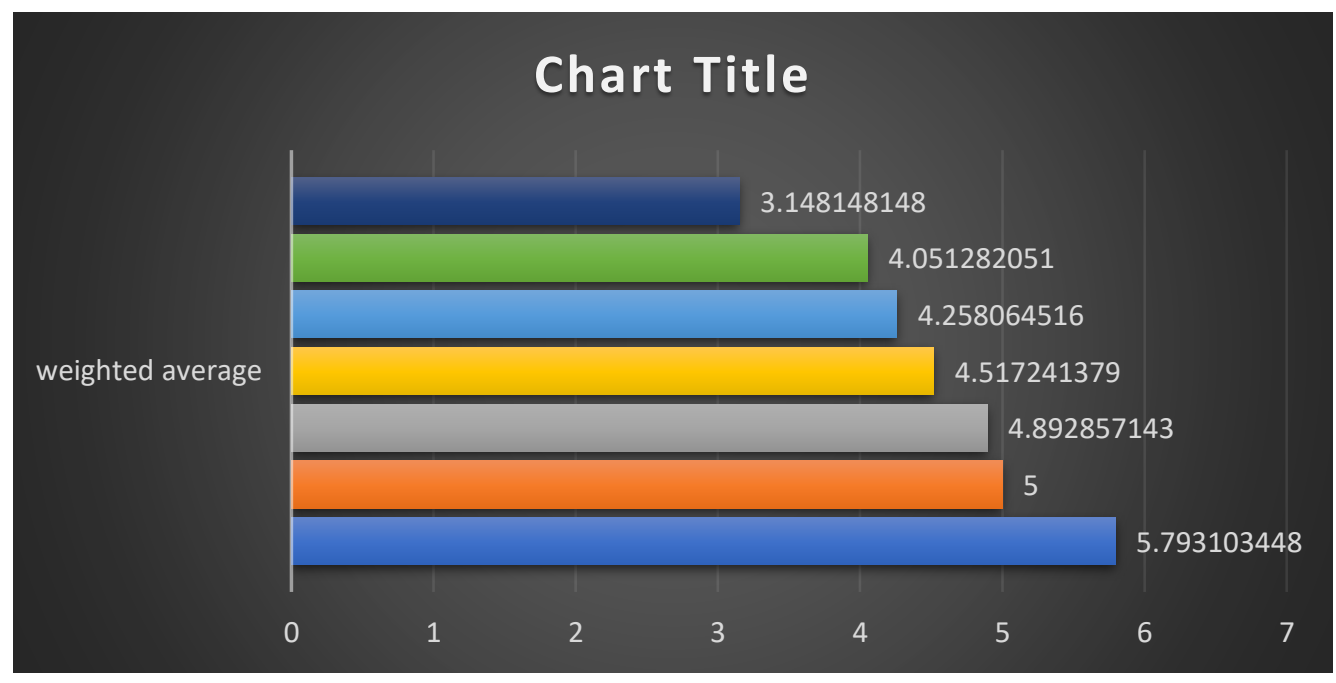

To manage the assets in such a way that leads to client's Interest in highest priority 1

To give proper disclosure of financial risk and return 2

To make a reasonable efforts to achieve the result 3

To observe the high standard of ethics 4

To conduct the diligence in making and maintaining the investment 5

To disclose the ,Environment, social and Governance risk 6

To disclose the amount of compensation he would get due to client's investment $\quad 7$

Figure 7: weighted average of expectation of fiduciary responsibility

\section{Attribute ranking}

\begin{tabular}{|l|c|}
\hline \multicolumn{1}{|c|}{ EXPECTATIONS FROM FIDUCIARY } & RANK \\
\hline $\begin{array}{l}\text { Manage the assets in such a way that leads to client's interest in highest } \\
\text { priority }\end{array}$ & 1 \\
\hline To give proper disclosure of financial risk and return & 2 \\
\hline To make a reasonable effort to achieve the result & 3 \\
\hline To observe the high standard of ethics & 4 \\
\hline To conduct the diligence in making and maintaining the investment & 6 \\
\hline To disclose the Environment, social and Governance risk & 7 \\
\hline $\begin{array}{l}\text { To disclose the amount of compensation he would get due to client's } \\
\text { investment }\end{array}$ & 5 \\
\hline
\end{tabular}

Table 1. Ranking of expectations from fiduciary

$\mathrm{H}_{0}$ : There is no association between the age and the selection of investment avenues.

$\mathrm{H}_{1}$ : There is an association between the age and the selection of investment avenues. 
For finding out the association we have applied the Pearson's Chi square test of independence.

We used SPSS 16 for performing this test and the results are as follows

\section{Crosstabulation}

Count

\begin{tabular}{|cl|l|l|l|l|l|}
\hline & \multicolumn{2}{l|}{ age } & \multicolumn{2}{l|}{ Total } \\
\cline { 3 - 6 } & & & $21-40$ & $40-60$ & 60 and above & \\
\hline \multirow{2}{*}{ Invst_avenue of above } & Life Insurance Fund & & 5 & 3 & 0 & 8 \\
& Mutual Fund & 13 & 1 & 0 & 14 \\
Total & & 23 & 3 & 2 & 29 \\
\hline
\end{tabular}

Table 2

Chi-Square Tests

\begin{tabular}{|l|l|l|l|}
\hline & Value & df & $\begin{array}{l}\text { Asymp. Sig. (2- } \\
\text { sided) }\end{array}$ \\
\hline $\begin{array}{l}\text { Pearson Chi-Square } \\
\text { Likelihood Ratio } \\
\text { N of Valid Cases }\end{array}$ & $\begin{array}{l}6.847^{\mathrm{a}} \\
7.022\end{array}$ & 6 & .335 \\
51 & 6 & .319 \\
\hline
\end{tabular}

\section{Table 3}

a. 9 cells $(75.0 \%)$ have expected count less than 5 . The minimum expected count is 16 .

$p=6.487$ which is greater than $5 \%$ we can say that there is no significant association between the age and the choice of investment avenue, which is really surprising. This may be due to the different types of mutual funds scheme available to suit the risk appetite of the investors which offer them different options.

\section{Interpretation}

From the above analysis we can conclude that the young respondents are very much inclined towards the investment in mutual fund with an objective to get risk adjusted return. The fees charged by mutual fund do not have any relationship with the expectation of fiduciary responsibility. The different kinds of expectations have been listed down to rank, and "to manage the assets in such a way that leads to the highest priority to the client's interest has been rated on highest priority from the investors "and "to disclose the amount of compensation the fiduciary would get from the client's investment has been rated at last priority which shows that 
the investors are not bothered about the how much fiduciary is earning by investing their money they are more concern about their financial risk and return.

\section{Conclusion}

The fiduciary duty concept is not new concept .It is been existed in financial market since its inception. Though, the concept of fiduciary duty is not new but considering the current issues like climate change financial crises, it has to be reformed. At global level some developed and developing countries have already reformed their fiduciary duty by implementing responsible investment strategy which includes Environment, social and Governance factors (ESG) into investment decision making process for the long term financial health of the investment and sustainable financial return. In India also common stewardship code has set up but that has to be further detailed according to the category of the institutional investors.

In India, still Inclusion of ESG factors has not yet prioritised as a fiduciary responsibility by beneficiary. This may due to lack of awareness among the retail investors. Institutional investors will be compelled to incorporate it as a fiduciary duty if it is demanded by the beneficiary. Here the role of regulators plays an important role as they are also protector of retail investor's wealth and regulate the institutional investors on their fiduciary duty. The changing fiduciary responsibility should be highlighted by the regulators. At the same it should guide the retail investors about the importance of ESG in the investment decision making process and its further advantage.

\section{Managerial implication}

Mutual fund managers should prioritised the investors' expectations while discharging their fiduciary responsibilities but at the same time they should also abreast themselves with international changes as the financial market has spread globally and those changes should be embedded in their strategy for the future.

\section{References}

1. Amalric Frank,:Article in Ecological Economics 59(4):440-450 · February 2006

2. Anagol, S., \& Kim, H. H. (2012). The Impact of Shrouded Fees: Evidence from a Natural Experiment in thev 2013 Indian Mutual Fund Market. American Economic Review, 576 593.

3. Barber, B., Zheng, L., \& Odean, T. (2005):. Out of Sight, Out of Mind: The Effects of Expenses on Mutual Fund Flows. Journal of Business , 2095-2120( 2004)

4. Barth, K., Karch, N.J., Mclaughlin, K. and Shi, C.S. :'Global retailing: tempting trouble', TheMcKinsey Quarterly, 1, pp. 117-125 (1996)

5. Chiyachantana, C., Jain, P., Jiang, C., \& Wood, R. :International evidence on institutional trading behavior and price impact. The Journal of Finance , 869-898. , 2004 
6. Deborah A. DeMott , :Forthcoming in Research Handbook on Mutual Funds (William A. Birdthistle \& John D. Morley eds., forthcoming 2016 Edward Elgar Publishing) (2016)

7. Stuart L. Gillan and Laura T. Starks Journal of Financial Economics, vol. 57, issue 2, 275305,2000 ,

8. John C. Bogle : The Fiduciary Principle: No Man Can Serve Two Masters The Journal Of Portfolio Management, (2009)

9. John P. Freeman,* Stewart L. Brown" \& Steve Pomerantz Mutual Fund Advisory Fees: New Evidence and a Fair Fiduciary Duty Test University of South Carolina Scholar Commons (2008)

10. Dr Janis Sarra : Fiduciary Obligations in Business and Investment: Implications of Climate Change, October 14, 2017

11. Keswani, A., \& Stolin, D. : Investor Reaction To Mutual Fund Performance: Evidence From UK Distribution Channels. Journal of Financial Research , 425-450. (2012)

12. Khorana et al. Khorana, A., Servaes, H., \& Tufano, P. (2005). Explaining the Size of the Mutual Fund Industry Around the World. Journal of Financial Economics , 50-56

13. La Porta, R., Lopez-de-Silane, F., Shleifer, A., \& Vishny, R. W.). Law and Finance. Journal of Political Economy , 106 ((1998)

14. Massa, M., Goetzmann, W. N., \& Rouwenhorst, G. K. : Behavioral Factors in Mutual Fund Flows. Yale ICF Working Paper No. 00-14, 42. (1999)

15. Nicola, C., \& Michele, G. Banking market structure, financial dependence, and growth: 16. International evidence from industry data. Journal of Finance , 617-648. ((2001).

17. Sarrow and Waitzer The Public Fiduciary: Emerging Themes in Canadian Fiduciary Law for Pension Trustees

18. Zechner et al,2011) Zechner, J., Neal, S., \& Youchang, W. (2011). Intermediated Investment Management. Journal of Finance , 947-980 ,2012)

19. www, watsonwyatt.com

Report

20. "Fiduciary responsibility legal and practical aspect of integrating ESG issues in institutional investment" UNEP FI July 2009

21. Fiduciary duty in 21 st century PRI, UNEP FI, UNEP Inquiry and UN Global Compact, September 2015

22. "Financial Services" Indian and Equity Foundation August 2018.

23. "Industry Trends “ Association Of Mutual Fund of India March 2018.

24. (PWC,CII June 2013) PWC, CII. (2013). Indian Mutual Fund Industry: Unearthing the growth potential in untapped markets 